\title{
Path analysis for selection of feijoa with greater pulp weight
}

\section{Joel Donazzolo ${ }^{1}$ Vanessa Padilha Salla ${ }^{2}$ Simone Aparecida Zolet Sasso ${ }^{2}$ Moeses Andrigo Danner ${ }^{2}$ Idemir Citadin ${ }^{2}$ Rubens Onofre Nodari ${ }^{3}$}

\author{
${ }^{1}$ Universidade Tecnológica Federal do Paraná (UTFPR), Km 04, 85660-000, Dois Vizinhos, PR, Brasil. E-mail: joel@utfpr.edu.br. \\ Corresponding author. \\ ${ }^{2}$ Programa de Pós-graduação em Agronomia, Universidade Tecnológica Federal do Paraná (UTFPR), Pato Branco, PR, Brasil. \\ ${ }^{3}$ Programa de Pós-graduação em Recursos Genéticos Vegetais, Universidade Federal de Santa Catarina (UFSC), Florianópolis, SC, Brasil.
}

\begin{abstract}
The objective of this paper was to identify the direct and indirect effects of feijoa fruits (Acca sellowiana) traitson pulp weight, in order to use these traits in indirect genotypes selection. Fruits of five feijoa plants were collected in Rio Grande do Sul, in the years of 2009, 2010 and 2011. Six traits were evaluated: diameter, length, total weight, pulp weight, peel thickness and number of seeds per fruit. In the path analysis, with or without ridge regression, pulp weight was considered as the basic variable, and the other traits were considered as explanatory variables. Total weight and fruit diameter had high direct effect, and are the main traits associated with pulp weight. These traits may serve as criteria for indirect selection to increase feijoa pulp weight, since they are easy to be measured.
\end{abstract}

Key words: Acca sellowiana, multicollinearity, ridge path analysis, indirect selection.

Análise de trilha para seleção de goiabeira-serrana com maior peso de polpa

RESUMO: O objetivo deste trabalho foi identificar os efeitos diretos e indiretos de caracteres dos frutos de goiabeira-serrana (Accasellowiana) sobre o peso de polpa, visando à utilização desses caracteres para a seleção indireta de genótipos. Foram coletados frutos de cinco grupo de plantas de goiabeira-serrana no Rio Grande do Sul, nos anos de 2009, 2010 e 2011. Seis caracteres foram avaliados: diâmetro, comprimento, peso total, peso de polpa, espessura da casca e número de sementes por fruto. Na análise de trilha com e sem regressão em crista para controle da multicolinearidade, o peso de polpa foi considerado variável básica e os demais caracteres considerados explicativos. O peso total, seguido do diâmetro de fruto, tiveram efeito direto elevado e são os principais caracteres associados ao peso de polpa. Estes caracteres podem servir de critérios de seleção indireta para aumentar o peso de polpa de goiabeira-serrana, pois são de fácil mensuração.

Palavras-chave: Accasellowiana, multicolinearidade, regressão em crista, seleção indireta.

\section{INTRODUCTION}

Feijoa [Acca sellowiana (Berg) Burret, family Myrtaceae - synonym Feijoa sellowiana] is native to the Brazilian Southern plateau and Uruguay (MATTOS, 1990). Feijoa fruit present translucent jelly-like pulp, with sweet acidulated flavor, and unique aroma (MATTOS, 1990). Due to its chemical composition, several studies have demonstrated the pharmacological properties of the species (WESTON, 2010), such as antibacterial, anti-inflammatory and antioxidant activities (KELES et al., 2012; MONFORTE et al., 2014); and to their antifungal activity against Candida glabrata, which is resistant to fluconazole (MACHADO et al., 2016).
The species is atthe initial domestication stage in its area of natural occurrence in Brazil, including the selection of genotypes with superior traits (SANTOS et al., 2005), and the development of four feijoa cultivars adapted to the conditions of the state of Santa Catarina (DUCROQUET et al., 2007, 2008). Owing to the fruits with unique characteristics, feijoa has potential for commercialization; however, it is still little commercially explored in Brazil (DUCROQUET et al., 2000; SANTOS et al., 2011). The species is cultivated in a domestic or extractive way, and few commercial orchards, since no improved cultivars adapted to all different regions of its natural occurrence have been developed yet. 
Colombia and New Zealand are among the largest feijoa producers, and these countries have made significant advances in the breeding of the species (THORP \& BIELESKI, 2002). In several other parts of the world, the plant has also undergone breeding process, such as in France, Israel, Italy, the former Soviet Union, and in the United States (THORP, 2006), Turkey (BEYHAN et al., 2011; BEYHAN \& EYDURAN, 2011). It has also been introduced in China, where adaptation studies are underway (TANG et al., 2016).

Indirect selection may facilitate and accelerate the selection of promising genotypes in feijoa genetic breeding, which requires the study of correlations between traits. Simple correlation coefficients are estimates of linear association between two traits; however, they do not consider the influence of other traits in the association. Conversely, the path analysis, proposed by WRIGHT (1921), demonstrates the unfolding of the correlation coefficient into direct and indirect effects of a group of traits (explanatory variables) on the expression of a more important trait for selection (basic variable), generating more accurate estimates of cause and effect (CRUZ \& CARNEIRO, 2006). For this reason, path analysisis a very useful tool in genetic breeding, especially of long selection cycle species, such as feijoa. Only one work has beenreported in the literature regarding path analysis on fruit species of the family Myrtaceae in Brazil, which detected fruit traits for indirect selection of pulp percentage and anthocyanin content of jabuticaba peel (SALLA et al., 2015).

The pulp is the edible part of the fruit, and also the most economically important (MATTOS, 1990). Therefore, it is one of the main traits to be improved in the obtainment of new genotypes. Proportion of pulp in relation to the total weight of the fruit is still low for the species, being around 30\% in cultivars already released in Brazil (DUCROQUET et al., 2007, 2008); although, some genotypes may present proportion that can reach close to $50 \%$ (MATTOS, 1990; DEGENHARDT et al., 2003). In addition, the measurement of pulp weight is laborious, since it is firmly adhered to the peel, and it can only be removed manually, using spoon-like devices, which hinders the obtainment of information. Thus, the objective of this research was to identify feijoa fruits traits for indirect selection of pulp weight.

\section{MATERIALS AND METHODS}

Five to ten mature fruits were collected per feijoa plants originated from five groups of plants from Rio Grande do Sul. Groups were denominated: 1) "Farmers": plants cultivated by farmers in the municipalities of Ipê, Monte Alegre dos Campos, and Antônio Prado. Fruits were collected from 17, 42 , and 37 plants in the years of 2009, 2010, and 2011, respectively; 2) "Backyards": plants grown in urban yards in the municipality of Vacaria. Fruits were collected from 10, 43, and 27 plants in the years of 2009, 2010, and 2011, respectively; 3) "Natural populations": plants originated from forest fragments in regeneration, in the municipalities of Ipê and Antônio Prado. Fruits were collected from 24 and 27 plants in the years of 2010 and 2011, respectively; 4) "SelCAV": plants grown in agroforestry systems, originated from mass selection of matrices, carried out in 2002. Fruits were collected from 20 plants in 2011; 5) "Chileans": plants grown in agroforestry systems in the municipality of Ipê and Antônio Prado, originated from germplasm imported from Chile. Fruits were collected from 16 plants in 2011.

In the laboratory, the following parameters were evaluated: diameter (measured in the equatorial part of the fruit), length (measured between opposite fruit sides), total weight, pulp weight, peel thickness, and number of seeds per fruit. Fruit diameter, fruit length and peel thickness were measured with a digital caliper. Weights were obtained using a precision scale, weighing the whole fruit and then the peel (after pulp removal).

Data of all the populations and years were grouped in the statistical analyses of each trait. Descriptive statistics were calculated to verify the variability of traits data. Assumptions of normality and homogeneity were verified by the Lilliefors and Bartlett tests. Afterwards, the Pearson's correlation coefficients were estimated between traits, whose significance was determined by the Student's $t$ test $(\mathrm{P} \leq 0.01)$.

Subsequently, the multicollinearity diagnosis was performed by the condition number analysis $(\mathrm{CN})$, which represents the ratio between the largest and the smallest eigenvalue of the correlation matrix. If $\mathrm{CN}<100$, collinearity is weak; If $100 \leq \mathrm{CN} \leq 1,000$, collinearity is moderate to strong; And if $\mathrm{CN}>1,000$, collinearity is severe (MONTGOMERY \& PECK, 1981). Path analysis was performed considering pulp weight as the basic variable (main dependent), and the other five traits were considered as independent or explanatory. With the multicollinearity, indicated by the condition number of 209.7 (moderate to strong) among the six traits, the ridge path analysis method, also called path analysis under multicollinearity, was applied (CARVALHO, 1994 ). In this strategy, a constant k 
is used, whose value must be the smallest as possible, in order to stabilize the path coefficients, and at the same time keep the variance inflation factor (VIF) lower than 10 , in all explanatory variables. This technique solves the problem of the multicollinearity effect, which can cause bias in the estimates of the direct and indirect effects between the variables. This technique avoids the exclusion of explanatory variables to maintain multicollinearity at acceptable levels. (CRUZ \& CARNEIRO, 2006; RIOS et al., 2012). For comparison purposes, a second single chain path analysis method (with no multicollinearity control) was performed, since the $\mathrm{CN}$ was close to the lowest limit to be considered weak multicollinearity $(\mathrm{CN}<100)$. All statistical analyses were carried out using the Genes software (CRUZ, 2013). Interpretation of the effects of the path coefficients was performed using the Pearson's correlation coefficients, according to LÚCIO et al. (2013).

\section{RESULTS AND DISCUSSION}

High variability was observed among feijoa fruit for the six traits, especially for total weight, pulp weight, and number of seeds per fruit (Table 1). This is very important for the selection of genotypes, since the existing variability allows selecting multiple traits, aiming to increase pulp yield, which is the in natura edible part, or that used in processed food or drinks (frozen pulp, juice, liquor, candies, etc). All the evaluated traits fulfilled the assumptions of normality and homogeneity by the Lilliefors and Bartlett tests, respectively.

In addition, all Pearson's correlation coefficients among the six traits were significant by the $t$ test $(P \leq 0.01)$, except for the number of seeds with diameter and pulp weight (Table 2). Coefficients were considered moderate $(0.50)$ to strong $(0.96)$ among the traits, except for the number of seeds, which had the lowest correlations with the other traits, demonstrating that the number of seeds in the fruits has low effect on the total weight and pulp weight, despite the wide variability reported for this traits in the evaluated fruits.

Comparing the two strategies of path analysis, without multicollinearity control (single chain path analysis) and with multicollinearity control (ridge path analysis), similar analysis performance was observed, since the determination coefficients were high $\left(\mathrm{R}^{2}=0.94\right.$ and 0.95$)$, and the effect of the residual variable was low $(0.25$ and 0.23$)$ (Table 3$)$.

This suggested that the two methods were accurate in estimating the direct and indirect effects (CRUZ \& CARNEIRO, 2006; RIOS et al., 2012). This similarity between the performance of the two methods of path analysis was due to the low degree of multicollinearity $(\mathrm{CN}=$ conditions number $=209.7)$, being close to the limit considered as weak, $\mathrm{CN}<100$ (MONTGOMERY \& PECK, 1981). Thus, the effect of bias correction by the method of multicollinearity control (ridge path analysis) was not as expressive as that of the method without multicollinearity control.

In contrast, for Jabuticabeira fruit traits set (SALLA et al., 2015), in which multicollinearity was severe $\left(\mathrm{CN}=5.15 \times 10^{9}\right)$, the use of ridge path analysis was necessary in order to correct the bias caused to the coefficient, even with more accurate estimates than the exclusion of the trait that caused multicollinearity (peel percentage).

The high determination coefficient and the effect of the low residual variable indicated the goodness of fit of the path analysis model, as well as the effective explanation of the effects of the five explanatory variables regarding the basic feijoa variable (pulp weight) (CRUZ \& CARNEIRO, 2006).

The total fruit weight had the highest direct effect on the basic trait (pulp weight). Fruit diameter

Table 1 - Descriptive statistics of six traits of feijoa fruit (Acca sellowiana).

\begin{tabular}{|c|c|c|c|c|c|c|c|c|}
\hline Variable & $\mathrm{N}$ & Minimum & Mean & CI (95\%) & Median & Maximum & SD & $\mathrm{CV}(\%)$ \\
\hline Diameter $(\mathrm{cm})$ & 2414 & 1.7 & 4.2 & $4.16-4.24$ & 4.2 & 7.1 & 0.9 & 21.4 \\
\hline Length (cm) & 2414 & 2.4 & 5.1 & $5.05-5.14$ & 5.0 & 9.6 & 1.1 & 21.6 \\
\hline Total weight (g) & 2414 & 6.0 & 54.9 & $53.65-56.15$ & 48.0 & 209.0 & 31.4 & 57.2 \\
\hline Pulp weight (g) & 2399 & 2.0 & 19.2 & $18.73-19.67$ & 16.1 & 94.0 & 11.8 & 61.5 \\
\hline Peel thickness $(\mathrm{cm})$ & 2381 & 0.2 & 0.5 & $0.49-0.51$ & 0.5 & 1.6 & 0.2 & 40.0 \\
\hline N. ofseeds & 239 & 21.0 & 90.6 & $85.97-95.23$ & 85.0 & 229.0 & 36.5 & 40.3 \\
\hline
\end{tabular}

CI: confidence interval of the mean, at $95 \%$ probability. SD: standard deviation of the mean. CV: coefficient of variation. 
Table 2 - Pearson's correlation coefficients in the upper diagonal, and associated probability, by the $\mathrm{t}(\mathrm{P} \leq 0.01)$ test, on the lower diagonal, among feijoa (Acca sellowiana) traits.

\begin{tabular}{|c|c|c|c|c|c|c|}
\hline Variables & Diameter & Length & Total Weight & Pulp Weight & Peel Thickness & N. ofseeds \\
\hline Diameter $(\mathrm{cm})$ & - & $0.833^{*}$ & $0.958^{*}$ & $0.890^{*}$ & $0.772^{*}$ & $-0.196^{\mathrm{NS}}$ \\
\hline Length $(\mathrm{cm})$ & $<0.0001$ & - & $0.884^{*}$ & $0.814^{*}$ & $0.659^{*}$ & $-0.253^{*}$ \\
\hline Total weight (g) & $<0.0001$ & $<0.0001$ & - & $0.911^{*}$ & $0.771^{*}$ & $-0.235^{*}$ \\
\hline Pulp weight (g) & $<0.0001$ & $<0.0001$ & $<0.0001$ & - & $0.500^{*}$ & $-0.136^{\mathrm{NS}}$ \\
\hline Peel thickness $(\mathrm{cm})$ & $<0.0001$ & $<0.0001$ & $<0.0001$ & $<0.0001$ & - & $-0.257^{*}$ \\
\hline N. ofseeds & 0.0119 & 0.0010 & 0.0024 & 0.0824 & 0.0009 & - \\
\hline
\end{tabular}

had significant explanatory effect on the definition of pulp weight. Both traits presented high and positive Pearson's correlation coefficients ( 0.91 and 0.89$)$ with pulp weight. However, in the path analysis, which demonstrated the cause and effect relationships, the effect of fruit weight on pulp weight is greater than that of the diameter.

The high and significant effect (0.81) of the length on pulp weight, detected by the simple correlation, was due to the indirect effect, mainly of the total weight, since the direct effect between fruit length and weight was low, proving not to be suitable for indirect selectionof feijoa fruits with greater pulp weight. Thus, the evaluation of the Pearson's correlation coefficients between these two traits would lead to the error of using it in the selection. This indicated the limitation of the coefficient of linear correlation and the advantage of the path analysis in the indication of the actual cause and effect relationships, since this analysis decomposes the coefficient of linear correlation, and demonstrated the direct effect of the explanatory trait on the basic trait, removing the indirect effects, and quantifying them (WRIGHT, 1921; CRUZ \& CARNEIRO, 2006). However, path analysis requires the evaluation of more than two response variables, which can be related, in order to identify the interrelationships between the traits, regardless of the others.

Number of seeds per fruit and peel thickness were also non-explanatory traits for the basic variable (pulp weight). In addition, both traits are difficult to be measured, and are traits of lesser relevance in the breeding of a fruit species. Therefore, these traits are not suitable for indirect selection of great pulp weight feijoa fruit.

Mainly the total fruit weight and fruit diameter can be measured and used for indirect selection of greater pulp weight of feijoa fruit. Since this association is directly proportional (positive sign of the correlation coefficient and ofthe direct effect), the selection of fruits with greater weight and greater diameter will be effective in the selection of fruits with greater pulp weight. This fact is important, since these two traits are easy to be measured by using a scale and a caliper, and also for they are not destructive, and the whole fruit can be used for other purposes after the measurements.

Other authors have determined the importance of path analysis to accelerate and facilitate the selection of genotypes with superior traits in breeding program of fruit species based on fruit morphological traits. In assai palm (Euterpe oleracea), fruit weight per bunch, number of bunches, and number of rachilles per bunch were determinant factors in the variation of fruit production of half-sib progenies, and can be used in the indirect selection of genotypes (TEIXEIRA et al., 2012). The mean pulp weight and number of fruits had a greater effect on the total weight of passion fruit (Passiflora edulis), and can be used to determine fruit yield in commercial cultivars and progenies of controlled hybridization originated from the breeding of the species (LÚCIO et al., 2013). Similar to the present results, pulp weight presented greater direct effect with fruit weight and equatorial diameter in a study carried out with 42 half-sib progenies of Passiflora edulis (NEGREIROS et al., 2007). In a study carried out with a species native to the south of Brazil, Plinia cauliflora, the peel percentageis the most determinant variable of pulp percentage, and the indirect selection for a smaller peel percentage may increase pulp percentagein the species (SALLA et al., 2015). In the present study, pulp percentage presented wide variation (between 7.3 and 64.9\%), with a mean of $35.4 \%$, which is slightly greater than the mean value of pulp yield ( 27 and $33 \%$ ) of the cultivars available in the market (DUCROQUET et al., 2007, 2008). 
Table 3 - Direct and indirect effects of feijoa fruit traits on pulp weight, estimated by Ridge path analysis (with multicollinearity) and single chain path analysis (without multicollinearity).

\begin{tabular}{|c|c|c|}
\hline Means of Association & Ridge path analysis & Single chain path analysis \\
\hline \multicolumn{3}{|c|}{-----} \\
\hline Direct effect on pulp weight & 0.451 & 0.421 \\
\hline Indirect effect via length & 0.041 & 0.014 \\
\hline Indirect effect via total weight & 0.789 & 0.867 \\
\hline Indirect effect via peel thickness & -0.389 & -0.407 \\
\hline Indirect effect via $n$. of seeds & -0.006 & -0.006 \\
\hline Total effect (Pearson's correlation) & \multirow{2}{*}{\multicolumn{2}{|c|}{ - }} \\
\hline 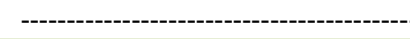 & & \\
\hline Direct effect on pulp weight & 0.049 & 0.017 \\
\hline Indirect effect via diameter & 0.376 & 0.351 \\
\hline Indirect effect via total weight & 0.728 & 0.800 \\
\hline Indirect effect via peel thickness & -0.332 & -0.348 \\
\hline Indirect effect via $n$. of seeds & -0.007 & -0.007 \\
\hline Total effect (Pearson's correlation) & \multicolumn{2}{|c|}{ 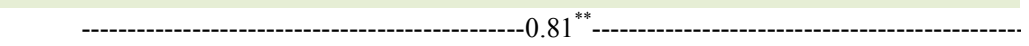 } \\
\hline \multicolumn{3}{|c|}{ 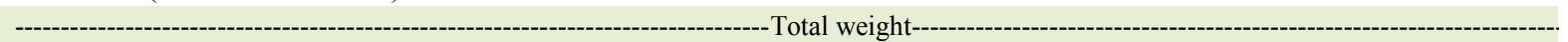 } \\
\hline Direct effect on pulp weight & 0.824 & 0.906 \\
\hline Indirect effect via diameter & 0.432 & 0.403 \\
\hline Indirect effect via length & 0.043 & 0.015 \\
\hline Indirect effect via peel thickness & -0.388 & -0.406 \\
\hline Indirect effect via $n$. of seeds & -0.007 & -0.007 \\
\hline Total effect (Pearson'scorrelation) & \multicolumn{2}{|c|}{ - } \\
\hline 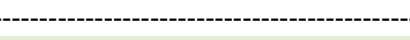 & ----------Pe & 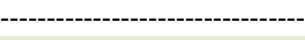 \\
\hline Direct effect on pulp weight & -0.503 & -0.527 \\
\hline Indirect effect via diameter & 0.348 & 0.325 \\
\hline Indirect effect via length & 0.032 & 0.011 \\
\hline Indirect effect via total weight & 0.635 & 0.698 \\
\hline Indirect effect via $n$. of seeds & -0.007 & -0.007 \\
\hline Total effect (Pearson'scorrelation) & \multicolumn{2}{|c|}{------------------------------------------------0.50 } \\
\hline 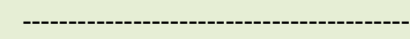 & ------------------ & 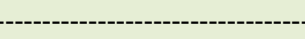 \\
\hline Direct effect on pulp weight & 0.029 & 0.029 \\
\hline Indirect effect via diameter & -0.088 & -0.082 \\
\hline Indirect effect via length & -0.012 & -0.004 \\
\hline Indirect effect via total weight & -0.194 & -0.213 \\
\hline Indirect effect via peel thickness & 0.129 & 0.135 \\
\hline Total effect (Pearson's correlation) & \multicolumn{2}{|c|}{ 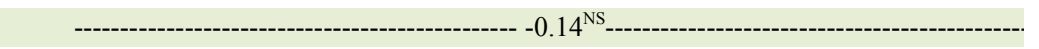 } \\
\hline \multicolumn{3}{|c|}{ } \\
\hline Determination coefficient $\left(\mathrm{R}^{2}\right)$ & 0.936 & 0.946 \\
\hline Effect of residual variable & 0.254 & 0.232 \\
\hline $\mathrm{CN}$ - Multicollinearity diagnosis & --------------- & --209.7------------------------- \\
\hline $\mathrm{K}$ value used in the analysis & 0.0087 & 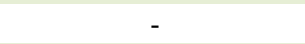 \\
\hline Maximum VIF & 7.3 & - \\
\hline
\end{tabular}

$\mathrm{NC}=$ Condition Number; Maximum VIF: the highest value of the variance inflation factor verified after applying the ridge path analysis. ${ }^{* *}$ Pearson's correlation coefficient significant by the t test $(\mathrm{P} \leq 0.01)$. 


\section{CONCLUSION}

Fruit weight and diameter are the main determining factors of Feijoa weight. For being easily measured, these two traits can serve as criteria for indirect selection to increase pulp weight in feijoa in breeding programs.

\section{ACKNOWLEDGMENTS}

To Coordenação de Aperfeiçoamento de Pessoal de Nível Superior (Capes), for the scholarship granted to JD; to the Araucária Foundation, for the financial support; to Conselho Nacional de Desenvolvimento Científico e Tecnológico (CNPq), for the financial support (Processes 562827/2010-2, 479778/20108) and the scholarship granted to RON; and to Fundação de Apoio à Pesquisa Científica e Tecnológica do Estado de Santa Catarina (FAPESC), for the financial support (Projects 9153/2010-7 and 5288/2011-4). To the Ecological Center and to the farmers involved in the implementation of the activities.

\section{REFERENCES}

BEYHAN, O. et al. Determination of macro-micro nutrient contents in dried fruit and leaves and some pomological characteristics of selected feijoa genotypes (Feijoa sellowiana Berg.) from Sakarya provinces in Turkey. Journal of Animal \& Plant Sciences, v.21, p.251-255, 2011. Available from: <http:// www.thejaps.org.pk/docs/21-2/10-126-RevisedFormated.pdf $>$. Accessed:Nov. 15,2015.

BEYHAN, O.; EYDURAN, S.P. Determination of promising native Feijoa (Feijoa sellowiana Berg.) genotypes from Sakarya Region in Turkey. Scientific Research and Essays, v.6, p.4104-4108, 2011. Available from: <http://www. academicjournals.org/journal/SRE/article-full-text-pdf/ CA448F627231>. Accessed: Nov. 15, 2015.doi: 10.5897/ SRE11.558.

CARVALHO, S.P. Métodos alternativos de estimação de coeficientes de trilha eíndices de seleção, sob multicolinearidade. 1994. 163f. Tese (Doutorado em genética e melhoramento) Universidade Federal de Viçosa, Viçosa, MG.

CRUZ, C.D. GENES - a software package for analysis in experimental statistics and quantitative genetics. Acta Scientiarum - Agronomy, v.35, n.3, p.271-276, 2013. Available from: <http:// www.scielo.br/pdf/asagr/v35n3/v35n3a01>. Accessed: Nov. 15, 2015. doi: 10.4025/actasciagron.v35i3.21251.

CRUZ, C.D.; CARNEIRO, P.C.S. Modelos biométricos aplicados ao melhoramento genético. Viçosa: UFV, 2006. 579p.

DEGENHARDT, J. et al. Plant phenotypic variation of two half sib families of feijoa (Accasellowiana Berg.) from an orchard in São Joaquim, SC. Revista Brasileira de Fruticultura, v.25, n.3, p.475-479, 2003. Availablefrom: $<$ http://www.scielo.br/scielo.php?script=sci arttext\&pid $=$ S0100-29452005000300029>. Accessed: Mar. 25, 2016. doi: 10.1590/S0100-29452005000300029.

DUCROQUET, J.P.H.J. et al. The first Brazilian feijoa cultivars: SCS 411 Alcântara e SCS 412 Helena. Agropecuária Catarinense, v.20, p.77-80, 2007. Available from: <http://intranetdoc.epagri. sc.gov.br/biblioteca/publicacoes/rac/edicoes_anteriores/rac_71_ jul_2007_v2.pdf>. Accessed: Mar. 25, 2016.

DUCROQUET, J.P.H.J. et al. Goiabeira-serrana (Feijoa sellowiana). Jaboticabal: Funep, 2000. (Série Frutas nativas, 5).

DUCROQUET, J.P.H.J. et al. Two new Brazilian feijoa cultivars:SCS 414-Mattos and SCS 415-Nonante. Agropecuária Catarinense, v.21, p.79-82, 2008. Available from: <http:// intranetdoc.epagri.sc.gov.br/producao tecnico cientifica/ DOC_33031.pdf $>$. Accessed: Apr. 25, 2015.

KELES, H. et al. The effects of Feijoa sellowiana fruits on the antioxidant defense system, lipid peroxidation, and tissue morphology in rats. Pharmaceutical Biology, v.50, n.3, p.318325, 2012. Available from: < http://www.tandfonline.com/doi/ful 1/10.3109/13880209.2011.608074>. Accessed: Mar. 10, 2015. doi: $10.3109 / 13880209.2011 .608074$.

LÚCIO, A.D. et al. Relations between variables in passion fruit. Ciência Rural, v.43, n.2, p.225-232, 2013. Available from: <http:// www.scielo.br/pdf/cr/v43n2/a5513cr2012-0467.pdf >. Accessed: Oct. 10, 2016. doi: 10.1590/S0103-84782013000200006.

MACHADO, G.R.M. et al. Reversal of fluconazole resistance induced by a synergistic effect with Acca sellowiana in Candida glabrata strains. Pharmaceutical Biology, v.55, p.1-10, 2016. Available from: <http://www.tandfonline.com/doi/abs/10.31 09/13880209.2016.1158286>. Accessed:July 27, 2016. doi: 10.3109/13880209.2016.1158286.

MATTOS, J.R. Goiabeira-serrana - fruteiras nativas do Brasil. 2.ed. Porto Alegre: CEUE, 1990.84p.

MONFORTE, M.T. et al. Feijoa sellowiana Berg fruit juice: anti-inflammatory effect and activity on superoxide anion generation. Journal of Medicine Food, v.17, n.4, p. 455461, 2014. Available from: <https://www.ncbi.nlm.nih.gov/ pubmed/24433073>. Accessed: July 22, 2015. doi: 10.1089/ jmf.2012.0262.

MONTGOMERY, D.C.; PECK, E.A. Introduction to linear regression analysis. New York: John Wiley \& Sons, 1981. 504p.

NEGREIROS, J.R.S. et al. Relations among physical fruit traits and pulp contentin yellow passion fruit. Revista Brasileira de Fruticultura, v29, n.3, p.546-549, 2007. Available from: <http:// www.scielo.br/pdf/rbf/v29n3/a26v29n3.pdf>. Accessed: Ago. 10, 2015. doi: 10.1590/S0100-29452007000300026.

RIOS, S.A. et al. Path analysis for carotenoids in maize. Revista Ceres, v.59, n.3, p.368-373, 2012. Disponível em: <http://www.scielo.br/pdf/rceres/v59n3/a11v59n3. pdf $>$. Accessed: Nov. 18, 2015. doi: 10.1590/S0034$737 \times 2012000300011$.

SALLA, V.P. et al. Path analysis of jabuticaba tree fruit traits. Pesquisa Agropecuária Brasileira, v.50, n.3, p.218-223, 2015. Available from: < http://www.scielo.br/pdf/pab/v50n3/0100-204Xpab-50-03-00218.pdf $>$. Accessed: June 27, 2015.doi: 10.1590/ S0100-204X2015000300005.

SANTOS, K.L. et al. Genetic characterization of natural populations of pineapple guava (Acca sellowiana), with heterologous microsatellites markers. Biotemas, v.24, n.4, p.75- 
83, 2011.Available from: <https://periodicos.ufsc.br/index.php/ biotemas/article/viewFile/2175-7925.2011v24n4p75/20221>. Accessed: Mar. 25, 2016. doi: 10.5007/2175-7925.

SANTOS, K.L. et al. Domestication of the pineapple-guava (Acca sellowiana) in South Brazil. Agrociência, v.9, n.1-2, p.2933, 2005. Available from: <https://docs.google.com/viewerng/ viewer?url=http://www.acuedi.org/ddata/5589.pdf $>$. Accessed: Jan. 16, 2015.

TANG. L. et al. A preliminary study on introduction and cultivation of Feijoa sellowiana in China. Advance Journal of Food Science and Technology, v.11, n.1, p.43-48, 2016. Available from: <http://maxwellsci.com/msproof. php?doi=ajfst.11.2352>. Accessed: Ago.10, 2016. doi: 10.19026/ajfst.11.2352.

TEIXEIRA, D.H.L. et al. Genetic correlations and path analysis for yield fruits components of assai palm. Revista Brasileira de Fruticultura, v.34, n.4, p.1135-1142, 2012. Available from: <http://www.scielo.br/pdf/rbf/v34n4/22.pdf $>$. Accessed: Ago. 28, 2015. doi:10.1590/S0100-29452012000400022.

THORP, G. Feijoa. In: JANICK, J.; PAULL, R.E. (Eds.). The encyclopedia of fruit $\&$ nuts. London: CABI Publisher, 2006 p.526-534.

THORP, G.; BIELESKI, R. Feijoas: origins, cultivation and uses. Auckland: David Bateman, 2002. 87p.

WESTON, R.J. Bioactive products from fruit of the feijoa (Feijoa sellowiana, Myrtaceae): A review. Food Chemistry, v.121, v.4, p.923-926, 2010. Available from: $<$ http://www.sciencedirect.com/ science/article/pii/S0308814610001275>. Accessed: Sept. 25, 2015. doi: 10.1016/j.foodchem.2010.01.047.

WRIGHT, S. Correlation and causation. Journal of Agricultural Research, v.20, n.7, p.557-585, 1921. Available from: <https:// naldc.nal.usda.gov/naldc/download.xhtml?id=IND43966364\&con tent $=$ PDF $>$. Accessed: Sept. 29, 2015. 